\title{
Exploration of Silence's Motives Towards the Work Decisions: The Case of Jordanian Public and Private Schools
}

\author{
Osama Khaled Alkhlaifat \\ AlexandreLamfalussy Faculty of Economics, University of Sopron, Hungary \\ E-mail: Khlaifat77@gmail.com
}

Received: Feb 26, 2019 Accepted: Mar. 15, 2019 Online published: Mar. 28, 2019

doi:10.5296/jpag.v9i1.14432ＵRL: https://doi.org/10.5296/jpag.v9i1.14432

\begin{abstract}
The aim of this study has been to investigate and provide a deeper understanding of the motives of silence towards the participation in the work-related decisions, in both the public and private schools in the Jordanian capital (Amman). '100' teachers were interviewed using the semi-structured interviews through the available communication means. The pre-set questions were directed to the sample of the study to identify both the situations related to the decisions and motives leading to silence and non-participation from the respondents' point of view. The motives were classified according to the factors to which they belong, as well as the situations were classified according to each stage of the decision-making process, where some specialists in the field of human resources management had been asked to help in accomplishing the classification. The results showed that the largest percentage of respondents faced at least one situation in which they chose to remain silent. Most of the situations mentioned were related to the first and last stage of decision-making process (identifying the problem and following up the decision). The results also showed that most of the motives were related to the organizational practices by the officials, where the total iteration is twice as the personal motives.
\end{abstract}

Keywords: silence, silence's motives, decision making, employees' participation

\section{Introduction}

Silence comes as a result of many reasons and motives, including what is implicit, intentional and objective (Dyne et al., 2003; Morrison \& Milliken, 2000). Since we are about studying the silence towards the decisions, as an administrative issue, what concerns us here is the conscious silence that is based on a personal decision and clear reasons for the employee, that drives him not to participate, such as self-protection or the achievement of a goal or interest 
(Brinsfield, 2013).

This study seeks to provide a solid basis, for both managers and those involved in decision making, to correctly understand the nature of the motives and factors behind the problem of silence, not generally, but specifically towards participation in the decisions, which allows managements, especially human resources departments, to find the appropriate solutions and to properly guide efforts in the right manner with regard to this problem. Where the problem of silence represents a waste and abuse of staff experience as a source of information necessary for the work health and development. Therefore, the researcher believes that it is important to find a clear model and specialized measurement tool that enable us to identify the motives of silence towards the decisions, and to know the relative importance and magnitude of the impact for each motive and factor. Moreover, the researcher suggests that employing and using specialized measuring tools and avoiding the use of models and tools that deal with the problem of silence generally, ensures that decision makers have greater accuracy and a clearer understanding of the motives and sources of this problem.

In addition to providing a strong basis for understanding the problem of silence towards decisions, this research will show a part of the administrative behaviors practiced by principals and decision-makers in Amman governorate schools, which have a major role in this problem as well as other personal factors related to individuals.

\subsection{The Study Problem}

The problem of silence is one of the big issues because of the many factors that lead to it and the impact it has on all the administrative functions and daily activities within the organizations. Despite the volume of research about silence, most of them discussed silence and its motives towards the various administrative issues in general. The researcher suggests that the issues and situations vary in importance and sensitivity from the point of view of employees, thus the nature of the motives and factors may also vary. Therefore, this research comes to identify the motives leading to the problem of silence towards the decisions, specifically by identifying the situations related to the decision-making stages, that are interrupted by silence from the point of view of non-decision-making employees in public and private schools in Amman governorate. In this research, the researcher focuses on investigating the motives of the problem of silence, specifically towards participation in the decisions, rather than in previous research, which focused on identifying the motives of silence in general. This would help the concerned to build a specialized measuring tool, and also helps the decision makers in identifying the relative importance of the motives of silence and sorting them according to the extent of their impact on this managerial function.

\subsection{Objectives of the Study}

Several studies examined the silence's motives and factors and the reasons for feeling uncomfortable with talking about the work issues in general, whether with colleagues or the officials, so this study comes to look deeper into this problem and to provide a clearer image of the staff's behavior and their views towards the decisions, which could help us in determining the most influential factors in this problem. In addition to provide a strong basis 
for the development of a specialized measuring tool.

\section{Literature Review}

\subsection{Organizational Silence}

A lot of the studies have addressed the problem of organizational silence and discussed its nature, motives and the factors leading to it. Some definitions of organizational silence have interpreted it as an absence of the voice of the workers and their withholding of ideas, opinions and information related to the development and correction of the course (Pinder \& Harlos, 2001). Deniz et al. (2013) have conceptualized the silence and defined it as a deliberate abstention of the questions, ideas, opinions and sharing information on the work-related issues. Furthermore, it's defined as a staff preference to refrain from expressing their thoughts, opinions and feelings face-to-face with the problems of the organization in which they work (Morrison \& Milliken, 2000). However, the researcher suggests that the latter has reduced the problem of silence in not being able to disclose views and information only face to face, which means silence may disappear by providing channels of communication that the staff deems appropriate. In other words, the main reason for the silence is the lack of appropriate communication channels, if true, it is only one reason for silence.

In the light of the previous definitions, the researcher defined the organizational silence towards the decisions for the purpose of this study as: the conscious and deliberate abstention of employees from sharing information related to work problems and solutions, opinions on the solutions offered and contributing to the selection of the best among them, or even about the effectiveness of implementing these solutions on the ground. Thus, this definition serves the research since it defines the problem of silence and addresses the stages through which the work decisions pass.

The researches on the problem of silence have revealed many factors that are generally considered to be the basis for this problem. These factors have been classified into two groups according to their sources. The first group includes the factors that are related to the organizational issues, policies behaviors, the prevailing leadership styles, the way of using the authority and the organizational structures (Jain, 2015; Pinder \& Harlos, 2001; Zehir \& Erdogan, 2011). The second group includes the personal factors, which are related to differences in the individuals' values, beliefs, cultural and social level, and their abilities to perceive the surrounding (Robbins, 2001; Willman et al., 2006). These researches have reported many factors of the silence problem including; employees' fear of unexpected reactions on their participations, self-defense and protection, the positive social tendency to keep the relations among the individuals, the low self-estimate, lack of experience and the inability to influence the course of action and change (Dyne et al., 2003; Milliken et al., 2003; Perlow \& Repenning, 2009; Pinder \& Harlos, 2001). These factors vary from one study to another, since some of them emerge in some studies and do not appear in others, which is normal in the opinion of the researcher as he believes this discrepancy results from the nature of the situation or the administrative issues that have been studied. Table (1) shows these factors classified according to their sources. 


\subsection{Decision Making}

The decision is defined as a process in which we analyze problems, evaluate alternatives available, and select a solution from a collection of alternatives (Cabrerizo et al., 2013). The decisions are considered the core of the administrative process for their continuity and overlap with the five basic administrative functions, for example, when management practices the function of planning, they deciside on the goals for an organization's future direction and determining the missions and resources to achieve those targets in the short and long term (Nofal \& Yusof, 2013). In addition, when the management organizes its tasks and activities, it makes decisions on the size and shape of the organizational structure the lines of authorities, the divisions and the human resources that required (Okoye \& Ezejiofor, 2013), also when the management practices the leading function, they take a series of decisions to guide the roles and efforts of the subordinates, and seeks how to convince them rather that coerce compliance (Spears, 2010). Moreover, if we are to speak about the function of management in regards to control, a lot of decisions are taken on the appropriate work standards for evaluating the actual performance besides the decisions on the amendments and corrective action (Otley, 2003), and so the decision-making process continues with the continuation of the administrative process itself.

The process of decision-making passes through main phases (Saaty, 2008; Sirakaya \& Woodside, 2005). The first is to diagnosis the problem: This phase includes determining the nature of the situation that created the problem, the relative importance, determining its symptoms and causes, and the appropriate time to start solving them. Phase II Determining the possible solutions: In which solutions and alternatives to solve the problem of the decision are collected (Saaty, 2008). Where this phase could be affected by several factors, like the financial resources and time available for the decision maker (Snowden \& Boone, 2007). Phase III Evaluating the solutions put forward: The extent to which each of the proposed solutions is suitable, the ability to implement and achieve the objective all are determined at this stage (Sirakaya \& Woodside, 2005). Phase IV Choosing the right solution: After the evaluation and trade-off process among the available alternatives is completed, the most appropriate alternative is chosen, the one with which we expect to achieve the objectives, and which could be accepted by the employees (Saaty, 2008). Phase V Follow-up to the implementation: At this stage, the implementation process and the results achieved are evaluated to determine the degree of the effectiveness and success in achieving the goals. This phase contributes to increasing the realism of the decision, where it may be accompanied by amendments and early detection of the errors (Sirakaya \& Woodside, 2005). As well as it contributes to develop the sense of responsibility of subordinates and encourage them to participate in the decisions (Edwards \& Elwyn, 2009).

The decisions relies heavily on the availability and gathering the most amount of information about the problem subject of the decision from its various sources (Marusich et al., 2016), where the lack or inability to obtain such information forms a kind of danger and may lead to organizational failure (Snowden \& Boone, 2007). The existence of silence and the abstention of the employees to talk about the work issues leads to absence of the needed information or even providing incomplete information about work problems, thus the decision makers 


\section{Macrothink}

become unable to understand and identify them accurately (Marusich et al., 2016). Moreover, this problem could cause a decrease in the ability of the organization to detect the problems and diagnose them earlier or at the emerging of symptoms (Dedahanov \& Rhee, 2015), therefore the inability to avoid or rid of them before they get aggravated, and the cost of disposal comes greater. More clearly, the silence towards the decisions prevents the decision makers from answering many of important questions like; what is the problem needed to be solved? where and when does the problem occur? how and why does the problem occur? why the problem occurs in this way and this timing? for whom does it occur? and why does the problem occur for that person? (Marusich et al., 2016; Spencer, et al., 2012).

The researcher suggests that the problem of silence may affect the decisions and each stage of the process unevenly. Thus, the relevant importance of the silence's motives may vary at each of these stages. Therefore, the researcher seeks through this research to lay the corner-stone in understanding the effect of silence on the decisions at each stage.

Table 1. Factors of the organizational silence

\begin{tabular}{|c|c|c|c|c|c|c|c|c|c|c|}
\hline Source of factors & \multicolumn{3}{|c|}{ Organizational factors } & \multicolumn{5}{|c|}{ Personal factors } \\
\hline \hline Reference & $\begin{array}{c}\text { Abusing } \\
\text { of } \\
\text { formal } \\
\text { authority }\end{array}$ & $\begin{array}{c}\text { Lack of } \\
\text { management } \\
\text { support }\end{array}$ & $\begin{array}{c}\text { Lack of } \\
\text { trust }\end{array}$ & Injustice & $\begin{array}{c}\text { Fear of } \\
\text { negative } \\
\text { reactions }\end{array}$ & $\begin{array}{c}\text { Lack of } \\
\text { self- } \\
\text { estimation }\end{array}$ & $\begin{array}{c}\text { Pro- } \\
\text { social } \\
\text { silence }\end{array}$ & $\begin{array}{c}\text { Diffident } \\
\text { Silence }\end{array}$ & $\begin{array}{c}\text { Psychological } \\
\text { withdrawal }\end{array}$ & $\begin{array}{c}\text { Deviant } \\
\text { silence }\end{array}$ \\
\hline Morison \& Milliken, 2000 & $\mathrm{X}$ & $\mathrm{X}$ & $\mathrm{X}$ & $\mathrm{X}$ & $\mathrm{X}$ & & $\mathrm{X}$ & $\mathrm{X}$ & $\mathrm{X}$ & $\mathrm{X}$ \\
\hline Dyne et al., 2003 & & & & & & $\mathrm{X}$ & $\mathrm{X}$ & $\mathrm{X}$ & & \\
\hline Guenter et al., 2017 & $\mathrm{X}$ & $\mathrm{X}$ & $\mathrm{X}$ & & & & & & & \\
\hline Jain, 2015 & $\mathrm{X}$ & & $\mathrm{X}$ & & & $\mathrm{X}$ & $\mathrm{X}$ & & & \\
\hline Timming \& Johnstone, 2015 & $\mathrm{X}$ & $\mathrm{X}$ & & $\mathrm{X}$ & $\mathrm{X}$ & $\mathrm{X}$ & & & & \\
\hline Zehir \& Erdogan, 2011 & $\mathrm{X}$ & $\mathrm{X}$ & & & $\mathrm{X}$ & $\mathrm{X}$ & & $\mathrm{X}$ & & \\
\hline Rafferty \& Restubog, 2011 & $\mathrm{X}$ & & & $\mathrm{X}$ & & & & $\mathrm{X}$ & $\mathrm{X}$ & \\
\hline Burris et al., 2008 & $\mathrm{X}$ & & $\mathrm{X}$ & & $\mathrm{X}$ & & $\mathrm{X}$ & $\mathrm{X}$ & $\mathrm{X}$ & \\
\hline Bagheri et al., 2012 & $\mathrm{X}$ & $\mathrm{X}$ & $\mathrm{X}$ & $\mathrm{X}$ & & & & & & \\
\hline Dedahanov \& Rhee, 2015 & & $\mathrm{X}$ & $\mathrm{X}$ & & $\mathrm{X}$ & $\mathrm{X}$ & & & $\mathrm{X}$ & \\
\hline Pinder \& Harlos, 2001 & & $\mathrm{X}$ & $\mathrm{X}$ & & $\mathrm{X}$ & $\mathrm{X}$ & & $\mathrm{X}$ & $\mathrm{X}$ & \\
\hline Detert \& Burris, 2007 & $\mathrm{X}$ & $\mathrm{X}$ & & & $\mathrm{X}$ & & & & & \\
\hline Tan, 2014 & & & $\mathrm{X}$ & $\mathrm{X}$ & & & & & $\mathrm{X}$ & \\
\hline Whiteside \& Barclay, 2013 & & $\mathrm{X}$ & & $\mathrm{X}$ & & $\mathrm{X}$ & & & $\mathrm{X}$ & \\
\hline Knoll \& Van Dick, 2013 & $\mathrm{X}$ & & & & $\mathrm{X}$ & & $\mathrm{X}$ & & $\mathrm{X}$ & $\mathrm{X}$ \\
\hline Rhee et al., 2014 & $\mathrm{X}$ & & & & $\mathrm{X}$ & $\mathrm{X}$ & $\mathrm{X}$ & $\mathrm{X}$ & $\mathrm{X}$ & \\
\hline Brinsfield, 2013 & & & & & $\mathrm{X}$ & & $\mathrm{X}$ & $\mathrm{X}$ & $\mathrm{X}$ & $\mathrm{X}$ \\
\hline Khalid \& Ahmed, 2016 & & & & & $\mathrm{X}$ & $\mathrm{X}$ & $\mathrm{X}$ & $\mathrm{X}$ & $\mathrm{X}$ & \\
\hline Bisel \& Arterbum, 2012 & & $\mathrm{X}$ & $\mathrm{X}$ & & $\mathrm{X}$ & $\mathrm{X}$ & & $\mathrm{X}$ & $\mathrm{X}$ & \\
\hline
\end{tabular}

Prepared by the researcher

\section{The Methodology}

\subsection{The Society and Study Sample}

This study is considered exploratory and aims at providing a better understanding of the problem of silence, factors, and motives at every stage of the decisions. Where the researcher did not find a guidance to indicate the appropriate sample size in this type of studies. Mason (2010) in his study about the sample size found that the average sample in such qualitative interviews is "31", where "560" qualitative researches are included in his analysis on this issue. Furthermore, the previous studies suggests that the sample should be sufficient to represent all the subjects in the study society (Milliken et al., 2003). The current study 
examines the problem of silence in the schools of Amman Governorate, precisely for non-decision-makers, where the target group is the teachers in both public and private sectors. Based on that and on the nature of the study society, where all individuals practice the same job and tasks, the researcher believes that a sample of '100' subjects will be sufficient and representative, especially that the respondents have been asked to mention at least one situation related to the decisions besides the motives that led them to keep silent. For that, the causes and situations would exceed the number of respondents.

The interviews were conducted with 100 teachers of both genders, who have a full-time work, where the percentage of teachers from the public schools is (41\%) compared to (59\%) from the private schools. The percentage of female teachers is (54\%), and the percentage of those who had previous work is (34\%). The researcher reached at the sample of the study through the social media and the electronic groups of teachers (Facebook and WhatsApp groups). To determine who are willing to participate, the nature of the study and its focus on the silence's motives had been clarified. After that, a coordination was done on how to interview each one according to his/her discretion (personal, telephone, video call).

\subsection{Study Limitations}

Despite the multiplicity of methods used to conduct interviews, some of them, precisely those conducted through phone calls, did not give the researcher an opportunity to clarify more about the responses. As well as, they did not provide the respondent the right climate to remember all the motives and situations in which he/she preferred to keep silent. Furthermore, this study focusses on the problem of silence in the Jordanian schools, which may cause the results to be affected by the national culture, thus their validity may be limited to the Jordanian society.

\subsection{Data Collection}

Each subject was interviewed independently and in the way he/she was available (telephone, video call, and personal interview). The duration of the interview ranged from 13 to 25 minutes, during which the research's questions were discussed with the respondents (see Appendix 1). The researcher recorded the relevant responses, that directly answer the research questions, in the form of points so that they could be formulated later in general exemplars describing the similar situations and motives which are related to the scope of the research.

At the beginning of each interview, the nature and purpose of the study were clarified, and the information of the personal respondents would not be available to anyone (see Appendix 1). The preset questions were addressed and discussed with the respondents: (1) Did you have a previous educational job? (2) To what extent do you prefer silence and not to go into business decisions? this question is based on the Likert's five degrees scale, in which (1) indicates no silence at all and (5) a permanent silence towards decisions. (3) If you have previously intended or been forced to remain silent and not to participate in decisions concerning work, what is the nature of the participation or situations you chose silence towards? to help manage this question, the following questions were used: (A) What kind of participation 
could you contribute? (B) What are the motives behind your silence? (C) What are the expected results or reactions if you decide to speak and not to remain silent in this case?

To achieve the objectives of the study, the researcher explained the nature of the decision-making process and its stages during the interviews. Moreover, to avoid missing any answer serving the search, the researcher asked the sample subjects, pricesely those who have shown no tendency to remain silent or who are rarely silent, to talk about the situations they have witnessed, and the motives they believe are behind their colleagues' silence.

\subsection{Interpreting Responses and Deriving Causes and Situations}

In order to derive the situations in which the respondents chose the silence and the motives that led to that, the researcher has done a preliminary reading of the responses and developed two lists. The first list included the decisions-related situations, while the another included the motives behind the silence. The two lists contained exemplars describing the similar situations and motives in general. Later, the researcher, more accurately, examined the sample responses several times to avoid loss of any point and to indicate the iteration of each situation or motive. This process was accompanied each time by amendments to the exemplars that were formulated to be clearer and more accurate.

\subsection{Classification of Situations and Motives}

To avoid waste of time and effort in previously discussed topics, the researcher prepared a list of silence' factors that are reported by the previous researches, to use them in classifying the motives, each according to the factor to which it belongs (Appendix 2B). Regarding to the decision-related situations, they have been classified each according to the stage to which it belongs (Appendix 2A). The researcher gave a number for each factor and each stage to facilitate the process of classification.

Assistance had been obtained from five specialists in the HR and business management field, who have the needed experience and knowledge to complete the classification process. The researcher sent the lists of motives and situations after being coded and sorted in descending order, from the most iterated to the least. The situations are indicated by the symbol (S) and the motives with (M), see (Appendix 3 A and B). The specialists were asked to assign only one factor for each of the mentioned motives, in addition to assigning one stage of decision-making stages for each of the situations they believe to be related. They were asked to write down the symbol in front of each exemplar. Otherwise, the symbol (0) is assigned to indicate that the exemplar is not associated with any of the factors or stages mentioned. The results show that, all the motives reported by the respondents were related to the factors mentioned in the list. Based on the results of the classification, the researcher rearranged the motives according to the factors to which they belong, and the situations according to each stage of the decision-making process, see (Appendix 4 A and B).

\section{The Results}

The results of the question that measures the employees' tendency to be silent towards the decisions showed that, a large proportion (82\%) prefer silence on participation in some situations, if not all. That's by looking at those who admit that they prefer to remain silent 
always, often, or sometimes, while (18\%) said they do not prefer silence or rarely remain silent (see Table 2). These percentages give a preliminary indicator on the existence of the problem of silence within the study society.

Table 2. The tendency towards the silence

\begin{tabular}{l|r}
\hline \multicolumn{2}{c}{ Sample's tendency to the silence } \\
\hline Never & 4 \\
\hline Rarely & 14 \\
\hline Sometimes & 44 \\
\hline Frequently & 31 \\
\hline Always & 7 \\
\hline
\end{tabular}

\subsection{Decision-Related Situations}

The number of independent decision-related situations that discussed during the interviews were (26) repeated (120) times. These situations were classified by the specialists as mentioned above. After that, the reliability of the classification was examined to see the degree of consistent among the specialists' opinions, where Cronbach's Alpha is $(86.1 \%)$, which indicates the ability of adopting the results of the classification. The results show that most of the mentioned situations, (41) of the total situations with percentage of (34\%), are related to the non-disclosure of work problems. The situations that represent the stage of development of alternatives or solutions amounted to (18\%) that is (22) situations. Regarding the stage of alternatives evaluation, the discussed related situations are (13\%) with (15) repetitions. The percentage of the situations associated with the stage of choosing the alternative is (11\%) with (13) repetitions. While the stage of following-up the decision was (24\%) with (29) repetitions, (See Table 3). The following quotes give examples on the sample's responses for each stage of decision-making process:

\subsubsection{Defining the Problem}

"... When a colleague is absent, the workload is distributed unfairly... those who are close to the management are always excluded of this work and this causes problems and a state of discontent ... For me, I do not speak because I am not close to the management, and I could be harassed in case of objection or my contract could be terminated as I work in a private school. In short, to be silent and follow the instructions means the satisfaction of management ..."

\section{"Female teacher, private school"}

"... At times of rest, we sit down and complain about work problems or mistakes made by colleagues that the management has no knowledge about... I avoid transferring them to the management because that could cause me to lose the trust of my colleagues, especially that the management is not keen on the confidentiality of the source of information and observations which may cause us problems with colleagues..."

\section{"Male teacher, public school"}




\subsubsection{Development of Solutions and Alternatives}

"We organized an open day to raise awareness about diseases and methods of infection, which requires hosting the specialists such as doctors, but the surprise was that the event did not include any specialist and there was a band; it was like an entertainment party and the content of the event was not as advertised, it was just a waste of money... I was very upset, but I did not make any comments about that... I was newly appointed, and my job status did not allow me to intervene, in addition the management did not ask for our opinion or put the matter to the discussion.

\section{"Male teacher, public school"}

"... I tried to interfere in the distribution of the teaching load, I suggested some amendments to be fairer and more satisfactory to all. I pointed to the injustice and dissatisfaction with the distribution method of some colleagues, but there was a misunderstanding for my opinion and my colleagues did not support me... All I got was a management enmity and a decrease in the annual assessment, after that I decided not to interfere in the decisions to avoid repeating what happened to me..."

\section{"Female teacher, public school"}

"... We were discussing about holding lectures on how to deal with bullying problems among the students, among those present was our colleague who is the educational counselor. At first, I wanted to suggest him to give the lectures in order to save the fees of the external lecturers, but I was afraid that he would be bothered by my suggestion since it would increase his workload... In addition to that, the management may take my opinion as lack of confidence in its ability to manage the school's financial resources ... "

\section{"Male teacher, public school"}

\subsubsection{Evaluation of Alternatives}

"... We were about setting up a schedule for parents' meetings... all suggested appointments were during the time of work, I was sure that most of them would not be able to come because of their working conditions, but I did not intervene because I was sure they would not take my opinion as usual... they do what is right for them regardless if it is true or not ... "

\section{"Female teacher, public school"}

"... we have a development committee composed of a number of teachers and it is responsible for developing the school environment. They suggested some programs and it was clear that some of them cost more than their benefit, but no one intervened or pointed that. I think that the members of the committee are our colleagues, and no one wants to sacrifice their relationship with them ... I did not intervene, I do not want to enter into a futile debate, and I do not interfere in the case that the decisions do not influence my work or do not affect me personally ..."

\section{"Female teacher, public school"}




\subsubsection{Choosing the Best Alternative}

"... There were several places to visit on a school trip for students, including a place suitable for that time of year and most importantly it is safe and suitable for the ages of students, but I did not participate in the choice of destination for fear of taking responsibility in case of any emergency... generally I prefer to keep far from the administrative issues and decisions to avoid any responsibility ..."

\section{"Female teacher, private school"}

"... Several appointments were suggested for the start of end-of-term exams. The best option in my opinion was to start and finish before the festivals season; this could satisfy the parents and the students... I did not give my opinion because this requires more effort to finish my work earlier... actually I am frustrated with my current job and feel dissatisfied; that is why I don't want to do more efforts..."

\section{"Female teacher, private school"}

\subsubsection{Monitoring and Evaluation of the Decision}

"... a charitable fundraising day was organized to help poor students as a kind of social solidarity... but the invitation was limited to the local families, and the results would have been better if the owners of profitable companies and organizations had been invited; this would activate their social role... but the management didn't discuss the situation and I'm sure they will not admit its mistake to not invite them ..."

\section{"Male teacher, public school"}

"... The so-called moving classes have been applied, where each teacher has a fixed classroom and the students move among their teachers. I had several observations that this decision was a danger to students because of the number of students passing within a short period. I did not intervene because I was newly appointed in the school and my job is teaching only... I do not think my opinion will make a difference in administrative matters which I prefer to leave to the most experienced owners ..."

\section{"Female teacher, public school"}

As we have said before, as each respondent has the opportunity to mention more than one situation related to decisions with the reasons of silence, it means that the situations exceeded the sample size. In addition, the same respondent may mention more than one situation regarding the same stage of decision making, which means that ten situations related to identifying the problem, for example, do not necessarily represent $10 \%$ of the respondents because these situations may be mentioned by three or four individuals. Therefore, the percentages which are mentioned in the table indicate the size of the situations mentioned in relation to the total number of responses. 
Table 3. The frequency of situations within each stage

\begin{tabular}{l|c}
\hline \multicolumn{1}{c|}{ Stage of the decision-process } & Freq \\
\hline Defining the problem & 41 \\
\hline Development of alternatives & 22 \\
\hline Evaluation of alternatives & 15 \\
\hline Choose Alternate / Solution & 13 \\
\hline Supervision and follow-up & 29 \\
\hline \multicolumn{1}{c}{ Total } & 120 \\
\hline
\end{tabular}

\subsection{Silence's Factors and Motives}

The results provided a good indicator on the weight of each factor and its magnitude in the problem of silence towards decisions, that is by finding the total frequency of the motives mentioned in each factor, (see Table 4).

The respondents reported (62) different motives repeated (332) times during interviews, i.e., each respondent reported an average of three to four motives for their silence towards the situations they mentioned. These motives are classified by the specialists according to the factors which they belong to. Then, the reliability test was conducted to see the degree of consistent among the specialists' opinions, where Cronbach's Alpha was (88.1\%), which indicates that the results of the classification can be adopted. The results show that, the administration's lack of objectivity and considering the discussions in a subjective way was the most frequent motive (13\%), followed by the fear of negative impact on the performance assessment (12\%), followed by the other motives, (see Appendix 3B). Regarding the factors, the results also showed that the total frequency of motives related to organizational factors reached (217) that is (65\%) of the total, while the personal factors (115) equal to (35\%). Table (3) Shows both organizational and personal factors sorted in descending order, where the most iterated organizational factors were the fear of negative reactions while the factor of maintaining social relations was the most prominent among the personal factors.

Table 4. The frequency of silence's motives within each factor

\begin{tabular}{|c|c|c|c|}
\hline \multicolumn{4}{|c|}{ Factors } \\
\hline Organizational factors & Freq & Personal factors & Freq \\
\hline Fear of negative reactions & 66 & Pro-social silence & 43 \\
\hline Lack of trust & 60 & lack of self-estimation & 31 \\
\hline Lack of management support & 36 & Psychological withdrawal & 26 \\
\hline Abusing of formal authority & 28 & Diffident Silence & 9 \\
\hline Injustice & 27 & Deviant silence & 6 \\
\hline Total/Org. factors & 217 & Total/Personal factors & 115 \\
\hline \multicolumn{4}{|c|}{ Total 332} \\
\hline
\end{tabular}

\section{Discussion of Results}

The responses of the sample showed that most of the members preferred to remain silent about the decisions in certain situations, if not always. While a few of them indicated that 
they do not remain silent about decisions (Table 2), which means that silence could be a phenomenon in the schools' environment. The results also show that the problem of silence was largely concentrated in the first stage of decision-making (problem identification), where the respondents mentioned (41) situations regarding this stage (Table 3), in contrast with fewer situations related to the following stages (development of solutions and alternatives, evaluation of alternatives and choosing the best among them). Then the number of situations related to the follow-up and assessment stage went up again to (29) situations. As it's clear form these results, the concentration of the reported situations is in the first and last stage of decision-making process, which could be explained by the unwillingness of employees to transfer bad news about the work problems to their officials. This confirms that people feel uncomfortable to talk when the information is related to bad news or feedback (Ilgen, Fisher, $\&$ Taylor, 1979). The researcher also justifies that by the ease of remembering the problems faced by staff in contrast with the other situations, and because of their psychological impact on the individuals, especially those which could not talk about or haven't been solved (Thoits, 1994), that is clear since the most iterated situations (70 situations) represents silence and non-disclosure of problems, whether problems needed to make a decision or that resulted from the decisions taken (the first and last stage of decision-making process).

This study aims at providing a broader understanding for the silence towards the decisions, that is through linking the decision-related situations at which the employee chose to keep silent with their motives to do so. The results show that all the motives obtained through interviews, whether they are similar or different from those reported by the previous studies, have been classified under the factors reported by the researchers. Also, the results show that the most frequent motives are related to the organizational factors, where the fear of negative reactions on intervention or participation in the decisions is the most common factor, includes (9) motives that repeated (66) times, followed directly by the lack of trust among officials and employees, which includes (12) motives repeated (60) times, then the rest of the organizational factors (Table 4). The focus of the respondents on the organizational factors indicates that there is an imperfection in the administrative practices, besides a failure of people in the positions of responsibility to possess the qualities and ethics of the real leader, which in its turn greatly affect the willingness and readiness of the organization members to discuss the work issues and decisions (Zehir \& Erdogan, 2011). The results also show a number of personal factors associated with the individuals' characteristics, where the most prominent is the fear of affecting the social relationships, which included (5) motives that iterated (43) times, followed by the rest of personal factors (Table 4), which indicates the great tendency of individuals to maintain their relationships with coworkers, where this could be justified by the fact that individuals, generally, do not wish to work in an environment of distorted relationships (Willnat et al., 2002). The researcher, through his experience in the field of education, suggests that is logical for this factor has a significant impact on the tendency to silence within the schools' environment, where the work there is interrelated and requires great cooperation. Wherefore, any imbalance or weakness in the relations not only cause a sense of uneasiness at the work but requires the staff more effort to complete their work individually. The results also show the deviant silence as one of the personal factors, which aims at achieving benefits such as obtaining the administration satisfaction or ignoring 
the employee's mistakes in return for ignoring the wrong decisions or problems resulting on them. It is contrary to what Pinder \& Harlos (2001) mentioned in their study, where they referred to the deviant silence as the silence intended to harm the reputation of the organization or a colleague. It should be noted here that this factor was the least mentioned factor, where it incorporated (3) motives repeated (6) times only.

The significant difference in the frequency between the organizational and personal factors, shows the heaviness of the organizational factors in the problem the subject of the study (Table 4), which gives a good indicator that a large part of the problem could be addressed by taking the necessary regulatory action, such as reconsidering the policies of selecting individuals to fill positions of responsibility and staying away from the nepotism and seniority-based techniques. In addition to holding courses in modern management methods that develop the leadership qualities of the current officials. On the other hand, the part of the silence problem which is related personal qualities, could also be mitigated, for example, focusing on personal development courses, especially those related to shyness and low self-esteem (12 motives repeated 40 times), would make a big difference if treated.

Finally, in addition to providing an initial indicator on the heaviness of the organizational and personal factors in the problem of silence, this research shows many motives which weren't reported in the previous researches and are directly related to the decisions and their mechanism. Also, the results show many situations that represent each stage of the decision-making process, which provides a solid basis to construct a specialized measurement tool that composed of two parts, the first one measures the degree of participation in the decisions, while the other measures the degree of silence's motives. Thus, the researcher and the interested people could conduct more accurate quantitative studies on the problem of silence towards the decisions, which allow to determine the size and impact of both organizational and personal factors, and to examine whether these factors are equal or not in their impact within the environments of both public and private schools.

\section{References}

Bagheri, G., Zarei, R., \& Aeen, M. N. (2012). Organizational silence (basic concepts and its development factors). Ideal Type of Management, 1(1), 47-58.

Bisel, R. S., \& Arterburn, E. N. (2012). Making sense of organizational members' silence: A sensemaking-resource model. Communication Research Reports, 29(3), 217-226. https://doi.org/10.1080/08824096.2012.684985

Brinsfield, C. T. (2013). Employee silence motives: Investigation of dimensionality and development of measures. Journal of Organizational Behavior, 34(5), 671-697. https://doi.org/10.1002/job.1829

Cabrerizo, F. J., Herrera-Viedma, E., \& Pedrycz, W. (2013). A method based on PSO and granular computing of linguistic information to solve group decision making problems defined in heterogeneous contexts. European Journal of Operational Research, 230(3), 624-633. 


\section{MInstitute Macho $^{\text {Mnth }}$}

Journal of Public Administration and Governance

ISSN 2161-7104 2019, Vol. 9, No. 1

Dedahanov, A. T., \& Rhee, J. (2015). Examining the relationships among trust, silence and organizational commitment. Management Decision, 53(8), 1843-1857. https://doi.org/10.1108/MD-02-2015-0041

Deniz, N., Noyan, A., \& Ertosun, Ö. G. (2013). The Relationship between Employee Silence and Organizational Commitment in a Private Healthcare Company. Procedia - Social and Behavioral Sciences, 99, 691-700. https://doi.org/10.1016/j.sbspro.2013.10.540

Detert, J. R., \& Burris, E. R. (2007). Leadership behavior and employee voice: Is the door really open? Academy of Management Journal, 50(4), 869-884. https://doi.org/10.5465/amj.2007.26279183

Dyne, L. V., Ang, S., \& Botero, I. C. (2003). Conceptualizing employee silence and employee voice as multidimensional constructs. Journal of Management Studies, 40(6), 1359-1392. https://doi.org/10.1111/1467-6486.00384

Edwards, A., \& Elwyn, G. (2009). Shared decision-making in health care: Achieving evidence-based patient choice. Oxford University Press.

Guenter, H., Schreurs, B., van Emmerik, I. H., \& Sun, S. (2017). What Does it Take to Break the Silence in Teams: Authentic Leadership and/or Proactive Followership? AUTHENTIC LEADERSHIP AND SILENCE. Applied Psychology, 66(1), 49-77. https://doi.org/10.1111/apps.12076

Ilgen, D. R., Fisher, C. D., \& Taylor, M. S. (1979). Consequences of individual feedback on behavior in organizations. Journal of Applied Psychology, 64(4), 349. http://dx.doi.org/10.1037/0021-9010.64.4.349

Jain, A. K. (2015). An interpersonal perspective to study silence in Indian organizations: Investigation of dimensionality and development of measures. Personnel Review, 44(6), 1010-1036. https://doi.org/10.1108/PR-12-2013-0220

Khalid, J., \& Ahmed, J. (2016). Perceived organizational politics and employee silence: supervisor trust as a moderator. Journal of the Asia Pacific Economy, 21(2), 174-195. https://doi.org/10.1080/13547860.2015.1092279

Knoll, M., \& Van Dick, R. (2013). Do I hear the whistle...? A first attempt to measure four forms of employee silence and their correlates. Journal of Business Ethics, 113(2), 349-362. https://doi.org/10.1007/s10551-012-1308-4

Marusich, L. R., Bakdash, J. Z., Onal, E., Yu, M. S., Schaffer, J., O’Donovan, J., ... Gonzalez, C. (2016). Effects of information availability on command-and-control decision making: performance, trust, and situation awareness. Human Factors, 58(2), 301-321. https://doi.org/10.1177/0018720815619515

Mason, M. (2010). Sample size and saturation in $\mathrm{PhD}$ studies using qualitative interviews. In Forum qualitative Sozialforschung/Forum: qualitative social research (Vol. 11). http://dx.doi.org/10.17169/fqs-11.3.1428 
Milliken, F. J., Morrison, E. W., \& Hewlin, P. F. (2003). An exploratory study of employee silence: Issues that employees don't communicate upward and why. Journal of Management Studies, 40(6), 1453-1476. https://doi.org/10.1111/1467-6486.00387

Morrison, E. W., \& Milliken, F. J. (2000). Organizational silence: A barrier to change and development in a pluralistic world. Academy of Management Review, 25(4), 706-725. https://doi.org/10.5465/amr.2000.3707697

Nofal, M. I., \& Yusof, Z. M. (2013). Integration of business intelligence and enterprise resource planning within organizations. Procedia Technology, 11, 658-665. https://doi.org/10.1016/j.protcy.2013.12.242

Okoye, P. V. C., \& Ezejiofor, R. A. (2013). The effect of human resources development on organizational productivity. International Journal of Academic Research in Business and Social Sciences, 3(10), 250. https://doi.org/10.6007/IJARBSS/v3-i10/295

Otley, D. (2003). Management control and performance management: whence and whither? The British Accounting Review, 35(4), 309-326. https://doi.org/10.1016/j.bar.2003.08.002

Perlow, L. A., \& Repenning, N. P. (2009). The dynamics of silencing conflict. Research in Organizational Behavior, 29, 195-223. https://doi.org/10.1016/j.riob.2009.06.007

Pinder, C. C., \& Harlos, K. P. (2001). Employee silence: Quiescence and acquiescence as responses to perceived injustice. In Research in personnel and human resources management (pp. 331-369). Emerald Group Publishing Limited.

Rafferty, A. E., \& Restubog, S. L. D. (2011). The influence of abusive supervisors on followers' organizational citizenship behaviours: The hidden costs of abusive supervision. $\begin{array}{llll}\text { British Journal } & \text { 270-285. }\end{array}$ https://doi.org/10.1111/j.1467-8551.2010.00732.x

Rhee, J., Dedahanov, A., \& Lee, D. (2014). Relationships among power distance, collectivism, punishment, and acquiescent, defensive, or prosocial silence. Social Behavior and Personality: An International Journal, 42(5), 705-720. https://doi.org/10.2224/sbp.2014.42.5.705

Robbins, S. P. (2001). Values, Attitudes and Job Satisfaction; SP Robbins: Organizational Behavior. Prentice Hall of India.

Saaty, T. L. (2008). Decision making with the analytic hierarchy process. International Journal of Services Sciences, 1(1), 83-98. https://doi.org/10.1504/IJSSCI.2008.017590

Sirakaya, E., \& Woodside, A. G. (2005). Building and testing theories of decision making by travellers. Tourism Management, 26(6), 815-832. https://doi.org/10.1016/j.tourman.2004.05.004

Snowden, D. J., \& Boone, M. E. (2007). A leader's framework for decision making. Harvard Business Review, 85(11), 68. 
Spears, L. C. (2010). Character and servant leadership: Ten characteristics of effective, caring leaders. The Journal of Virtues \& Leadership, 1(1), 25-30.

Spencer, T. D., Detrich, R., \& Slocum, T. A. (2012). Evidence-based practice: A framework for making effective decisions. Education and Treatment of Children, 35(2), 127-151. https://doi.org/10.1353/etc.2012.0013

Tan, Ç. (2014). Organizational justice as a predictor of organizational silence. Educational Research and Reviews, 9(21), 1190-1202. https://doi.org/10.5897/ERR2014.1891

Thoits, P. A. (1994). Stressors and problem-solving: The individual as psychological activist. Journal of Health and Social Behavior, 143-160. https://doi.org/10.2307/2137362

Timming, A. R., \& Johnstone, S. (2015). Employee silence and the authoritarian personality: A political psychology of workplace democracy. International Journal of Organizational Analysis, 23(1), 154-171. https://doi.org/10.1108/IJOA-06-2013-0685

Whiteside, D. B., \& Barclay, L. J. (2013). Echoes of silence: Employee silence as a mediator between overall justice and employee outcomes. Journal of Business Ethics, 116(2), 251-266. https://doi.org/10.1007/s10551-012-1467-3

Willman, P., Bryson, A., \& Gomez, R. (2006). The sound of silence: which employers choose no employee voice and why? Socio-Economic Review, 4(2), 283-299. https://doi.org/10.1093/ser/mw1012

Willnat, L., Lee, W., \& Detenber, B. H. (2002). Individual-level predictors of public outspokenness: A test of the spiral of silence theory in Singapore. International Journal of Public Opinion Research, 14(4), 391-412. https://doi.org/10.1093/ijpor/14.4.391

Zehir, C., \& Erdogan, E. (2011). The Association between Organizational Silence and Ethical Leadership through Employee Performance. Procedia - Social and Behavioral Sciences, 24, 1389-1404. https://doi.org/10.1016/j.sbspro.2011.09.054

\section{Appendix 1}

\section{Interview guide}

This study is concerned with identifying the reasons for the silence of the staff towards decisions in the Jordanian public and private schools' environment by identifying the situations associated with the decision-making process in which you chose silence instead of speaking up and participating.

In this interview, we would like to ask you questions about the situations you have encountered regarding the decisions in your workplace, specifically those for which you have chosen to be silent, the motives and reasons behind the silence, so please speak freely and openly to make the most of this study. The identity and the personal information of the respondents are secret and not accessible to any official or other entity and cannot be accessed by anyone. 


\section{With respect}

1. Did you work in previous educational jobs?

2. In general, to what extent do you prefer silence and not to go into business decisions?

\begin{tabular}{l|l|l|l|l}
\hline Always & Frequently & Sometimes & Rarely & Never \\
\hline & & & & \\
\hline
\end{tabular}

3 - The process of decision-making passes through several stages (identifying the problem and pointing to it, providing solutions and alternatives, evaluating alternatives and expressing opinion, choosing alternatives, follow-up and giving opinions in the consequences of the decisions taken)

Have you ever had the opportunity to participate or have any information or opinion in any of the stages or situations related to the decision-making process and preferred to keep silent? mention in detail one or more of these.

During the interview, the following questions are used to help manage the interview:

A. What kind of participation could you contribute?

B. What made you silent/What are the motives behind your silence?

C. What are the expected results or reactions if you decided to talk and not to be silent in this case?

Appendix 2A: The factors of silence

\begin{tabular}{|l|c|}
\hline \multicolumn{1}{|c|}{ Factor } & Symbol \\
\hline \hline Abusing of formal authority & 1 \\
\hline Lack of management support & 2 \\
\hline Deviant Silence & 3 \\
\hline Lack of trust & 4 \\
\hline Injustice & 5 \\
\hline Fear of negative reactions & 6 \\
\hline lack of self-estimation & 7 \\
\hline Pro-social silence & 8 \\
\hline Diffident Silence & 9 \\
\hline Psychological withdrawal & 10 \\
\hline $\begin{array}{l}\text { Management fear of negative } \\
\text { reactions }\end{array}$ & 0 \\
\hline $\begin{array}{l}\text { If it doesn't belong to any of the } \\
\text { above }\end{array}$ & \\
\hline
\end{tabular}

Appendix 2B: Stages of the decision-making process 


\begin{tabular}{|l|c|}
\hline \multicolumn{1}{|c|}{ Stage } & Symbol \\
\hline \hline Defining the problem & 1 \\
\hline Development of alternatives & 2 \\
\hline Evaluation of alternatives & 3 \\
\hline Choose Alternate / Solution & 4 \\
\hline Supervision and follow-up & 5 \\
\hline
\end{tabular}

Appendix 3A: Decisions-related situations

\begin{tabular}{|l|l|c|}
\hline Seq & \multicolumn{1}{|c|}{ Situation } & Freq \\
\hline \hline S1 & Abstention of reporting work problems in general & 16 \\
\hline S2 & Abstention of reporting colleagues' mistakes & 10 \\
\hline S3 & Abstention of reporting troubles resulting from the decisions & 10 \\
\hline S4 & Abstention of suggesting solution/alternative that increases the workload & 6 \\
\hline S5 & Abstention of indicating the cost and the real value of the alternatives/solutions & 6 \\
\hline S6 & Abstention of suggesting some adjustments to the decision taken & 6 \\
\hline S7 & Abstention of reporting the problems that don't affect personally & 5 \\
\hline S8 & Abstention of suggesting any alternatives/solutions & 5 \\
\hline S9 & Abstention of indicating the illegal alternatives/solutions & 5 \\
\hline S10 & Abstention of indicating the best among the alternatives if not asked to do & 5 \\
\hline S11 & Abstention of choosing the alternative that satisfies all parties & 5 \\
\hline S12 & Abstention of indicating that the applied decision is wrong & 5 \\
\hline S13 & $\begin{array}{l}\text { Abstention of reporting the problems that are being committed by the employee } \\
\text { himself }\end{array}$ & 4 \\
\hline S14 & Abstention of suggesting the solution/alternative that satisfies all parties & 4 \\
\hline S15 & Abstention of suggesting the alternative that requires taking responsibility & 4 \\
\hline S16 & Abstention of indicating the appropriateness of the decision implementing timing & 4 \\
\hline S17 & Abstention of reporting the problems that are less important & 3 \\
\hline S18 & Abstention of reporting the problems that are expected not to be solved & 3 \\
\hline S19 & Abstention of suggesting more economically viable solutions/alternatives & 3 \\
\hline S20 & Abstention of indicating any deviation from the actual objectives & 3 \\
\hline S21 & Abstention of indicating the unrealistic of the alternatives/solutions & 2 \\
\hline S22 & Abstention of choosing the alternatives that requires more efforts & 2 \\
\hline S23 & Abstention of indicating that the alternatives are futile/not valuable & 1 \\
\hline S24 & Abstention of indicating the expected outcomes on the suggested alternatives & 1 \\
\hline S25 & $\begin{array}{l}\text { Abstention of choosing the alternative that is compatible with the available } \\
\text { capabilities }\end{array}$ & 1 \\
\hline S26 & Abstention of indicating that the used implementing methods are wrong & 1 \\
\hline
\end{tabular}




\section{Macrothink}

Journal of Public Administration and Governance

ISSN 2161-7104

2019, Vol. 9, No. 1

Appendix 3B: Reported silence motives and the iteration

\begin{tabular}{|c|c|c|}
\hline Seq & Silence Motive & Freq \\
\hline M1 & The management takes the discussion personally and not objectively & 13 \\
\hline M2 & To avoid any effect on my performance evaluation & 12 \\
\hline M3 & To avoid hurting my colleagues' feelings & 11 \\
\hline M4 & My participation might harm a colleague's job & 11 \\
\hline M5 & To avoid of losing the job & 10 \\
\hline M6 & To avoid any clashes and conflicts with the management & 10 \\
\hline M7 & To keep good relations with my colleagues & 10 \\
\hline M8 & Lack of appreciation on our efforts & 9 \\
\hline M9 & The management considers itself the only who has the right to take decisions & 8 \\
\hline M10 & The management does not support innovation & 8 \\
\hline M11 & The management underestimates our efforts and opinions & 8 \\
\hline M12 & The salary I get is not worth the efforts I do & 8 \\
\hline M13 & To avoid the responsibility in case of any mistake or failure of the decision & 8 \\
\hline M14 & The management is rigid in applying regulations and has no flexibility & 7 \\
\hline M15 & My participation could increase my workload & 7 \\
\hline M16 & To avoid being labeled as a troublemaker & 7 \\
\hline M17 & To avoid losing the trust of colleagues & 7 \\
\hline M18 & The management does not accept any debate about the decision & 6 \\
\hline M19 & The management does not support cooperation/teamwork & 6 \\
\hline M20 & The management takes decisions that meet their personal interests & 6 \\
\hline M21 & The management is unable to understand and interpret our views & 6 \\
\hline M22 & The management is not decisive towards troublemakers & 6 \\
\hline M23 & The management attributes the achievements to themselves & 6 \\
\hline M24 & The management does not differentiate between hard and inactive employees & 6 \\
\hline M25 & The work position does not allow to intervene in decisions & 6 \\
\hline M26 & Lack of awareness on some administrative issues & 6 \\
\hline M27 & Being silent brings me the tranquility & 6 \\
\hline M28 & If the decisions do not directly affect me or my work, I don't intervene & 6 \\
\hline M29 & The management does not give us an opportunity to participate & 5 \\
\hline M30 & The management considers us incapable to understand and take decisions & 5 \\
\hline M31 & The management is unable to solve the problems at work & 5 \\
\hline M32 & To avoid any personal offense by others & 5 \\
\hline M33 & My opinion will not make any impact & 5 \\
\hline M34 & To stay away from work issues and problems & 5 \\
\hline M35 & The management does not raise the issues for discussion & 4 \\
\hline M36 & $\begin{array}{l}\text { The management considers our intervention as a mistrust in its ability to make } \\
\text { decisions }\end{array}$ & 4 \\
\hline M37 & The management does not consider the privacy of people who report the problems & 4 \\
\hline M38 & The management considers any objection as a challenge/conspiracy against it & 4 \\
\hline
\end{tabular}




\section{Macrothink}

Journal of Public Administration and Governance

ISSN 2161-7104

2019, Vol. 9, No. 1

\begin{tabular}{|l|l|l|} 
M39 & The management listens only to the opinions of selected people & 4 \\
\hline M40 & Fear of being transferred to another work location & 4 \\
\hline M41 & Lack of the experience to discuss the work decisions & 4 \\
\hline M42 & The colleagues asked not to intervene with the decisions that affect them & 4 \\
\hline M43 & To avoid any embarrassment & 4 \\
\hline M44 & Nothing worth pay more efforts & 4 \\
\hline M45 & The management does not accept criticism on decisions & 3 \\
\hline M46 & The management doesn't admit its mistakes & 3 \\
\hline M47 & The management does not fairly apply procedures in case of problems and faults & 3 \\
\hline M48 & To avoid being labeled as a complainer & 3 \\
\hline M49 & Being afraid that colleagues won't support my opinions & 3 \\
\hline M50 & Unsure what to say. & 3 \\
\hline M51 & Frustrated with the current job & 3 \\
\hline M52 & Silence makes the management satisfied with me & 3 \\
\hline M53 & The management is skeptical about our information and its sources & 2 \\
\hline M54 & The management is not able to make any change & 2 \\
\hline M55 & My participation will be dismissed & 2 \\
\hline M56 & Not having the power or authority to change & 2 \\
\hline M57 & Lack of sufficient knowledge in legislation and regulations & 2 \\
\hline M58 & Because I do not want to appear incompetent & 2 \\
\hline M59 & To avoid contact with others in the work environment & 2 \\
\hline M60 & Silence brings me some personal interests with the management & 2 \\
\hline M61 & The inability to convince the others with my opinions & 1 \\
\hline M62 & If I keep silent, the management will skip on my mistakes & 1 \\
\hline
\end{tabular}

Appendix 4A: Classifying the situations according to the decision-making stages:

\begin{tabular}{|c|l|c|}
\hline Seq. & \multicolumn{1}{|c|}{ Defining the problem } & Freq \\
\hline \hline S1 & I see problems at work, but I prefer not to talk or discuss them in general & 16 \\
\hline S2 & I don't report my colleagues' mistakes & 10 \\
\hline S7 & I don't report the problems that don't affect me & 5 \\
\hline S13 & I don't report the problem that I cause & 4 \\
\hline S17 & I don't report the problems which aren't important & 3 \\
\hline S18 & I don't report the problems that I expect they couldn't be solved & 3 \\
\hline & \multicolumn{1}{|c}{ Total } & 41 \\
\hline
\end{tabular}

\begin{tabular}{|c|l|c|}
\hline Seq. & \multicolumn{1}{|c|}{ Development of alternatives } & Freq \\
\hline \hline S4 & I had better solutions but that would increase my workload & 6 \\
\hline S8 & I had solution to the problem, but I didn't speak it up & 5 \\
\hline S14 & I could suggest a solution that satisfy all parties, but I didn’t & 4 \\
\hline S15 & I had solutions that require me to take responsibility & 4 \\
\hline S19 & I had more economically feasible solutions, but I didn't share them & 3 \\
\hline & Total & 22 \\
\hline
\end{tabular}




\begin{tabular}{|c|l|c|}
\hline Seq. & \multicolumn{1}{|c|}{ Evaluation of alternatives } & Freq \\
\hline \hline S5 & The suggested solutions cost more than their value, but I didn't point that out & 6 \\
\hline S9 & Some solutions were contrary to laws and regulations, but I didn't point that out & 5 \\
\hline S21 & I could show that the suggested solutions were unrealistic, but I didn't & 2 \\
\hline S23 & Some offered solutions were futile, I didn't point that out & 1 \\
\hline S24 & $\begin{array}{l}\text { The expected outcomes on some alternatives were clear for me but I didn't point } \\
\text { that out }\end{array}$ & 1 \\
\hline & Total & 15 \\
\hline
\end{tabular}

\begin{tabular}{|c|l|c|}
\hline Seq. & \multicolumn{1}{|c|}{ Choose Alternate / Solution } & Freq \\
\hline \hline S10 & I could have pointed out the best solution if I had been asked & 5 \\
\hline S11 & I could have chosen the solution that satisfies all parties & 5 \\
\hline S22 & I could have chosen the best solution If it hadn't required me more effort. & 2 \\
\hline S25 & $\begin{array}{l}\text { I could have pointed the solution that is viable and compatible with the available } \\
\text { capabilities }\end{array}$ & 1 \\
\hline & \multicolumn{1}{|c|}{ Total } & 13 \\
\hline
\end{tabular}

\begin{tabular}{|c|l|c|}
\hline Seq. & \multicolumn{1}{|c|}{ Supervision and follow-up } & Freq \\
\hline \hline S3 & The applied decision caused some trouble at the work, But I didn't point that out & 10 \\
\hline S6 & I felt the results would be better with some adjustments, but I didn't point that out & 6 \\
\hline S12 & I realized, after the implementation, that the decision was wrong, but I didn't point that out & 5 \\
\hline S16 & I realized that the timing of the implementation was not appropriate, but I didn't point that out & 4 \\
\hline S20 & There was a deviation from the actual objective of the decision, but I didn't point that out & 3 \\
\hline S26 & The methods used to implement the decision were wrong, but I didn't point that out & 1 \\
\hline & Total & 29 \\
\hline
\end{tabular}

Appendix 4B: Classifying the motives according to their factors:

\begin{tabular}{|c|l|c|}
\hline Seq. & \multicolumn{1}{|c|}{ Fear of negative reactions } & Freq \\
\hline \hline M2 & To avoid any effect on my performance evaluation & 12 \\
\hline M5 & To avoid losing job & 10 \\
\hline M6 & To avoid any conflicts with the management & 10 \\
\hline M13 & To avoid the responsibility in the case of any mistake or failure of the decision & 8 \\
\hline M15 & My participation could increase my workload & 7 \\
\hline M16 & To avoid being labeled as a troublemaker & 7 \\
\hline M32 & To avoid any personal offense by others & 5 \\
\hline M40 & Fear of being transferred to another work location & 4 \\
\hline M48 & To avoid being labeled as a complainer & 3 \\
\hline & & Total \\
\hline
\end{tabular}




\begin{tabular}{|c|l|c|}
\hline Seq. & \multicolumn{1}{|c|}{ Lack of trust } & Freq \\
\hline \hline M1 & The management takes the discussion personally and not objectively & 13 \\
\hline M20 & The management takes decisions that meet their personal interests & 6 \\
\hline M21 & The management is unable to understand and interpret my views & 6 \\
\hline M22 & The management is not decisive towards troublemakers & 6 \\
\hline M30 & The management considers us incapable to understand and take decisions & 5 \\
\hline M31 & The management is unable to solve the problems at work & 5 \\
\hline M36 & $\begin{array}{l}\text { The management considers our intervention as a mistrust in its ability to make } \\
\text { decisions }\end{array}$ & 4 \\
\hline M37 & The management does not consider the privacy of people who report the problems & 4 \\
\hline M38 & The management considers any objection as a challenge/conspiracy against it & 4 \\
\hline M46 & The management doesn't admit its mistakes & 3 \\
\hline M53 & The management is skeptical about our information and its sources & 2 \\
\hline M54 & The management is not able to make any change & 2 \\
\hline & & 60 \\
\hline
\end{tabular}

\begin{tabular}{|c|l|c|}
\hline Seq. & \multicolumn{1}{|c|}{ Pro-social silence } & Freq \\
\hline \hline M3 & To avoid hurting my colleagues' feelings & 11 \\
\hline M4 & My participation might harm a colleague's job & 11 \\
\hline M7 & To keep good relations with my colleagues & 10 \\
\hline M17 & To avoid losing the trust of my colleagues & 7 \\
\hline M42 & My colleagues asked me not to intervene with the decisions that affect them & 4 \\
\hline & \multicolumn{1}{|c}{ Total } & 43 \\
\hline
\end{tabular}

\begin{tabular}{|c|l|c|}
\hline Seq. & \multicolumn{1}{|c|}{ Lack of management support } & Freq \\
\hline \hline M8 & Lack of appreciation on our efforts & 9 \\
\hline M10 & The management does not support innovation & 8 \\
\hline M11 & The management underestimates our efforts and opinions & 8 \\
\hline M19 & The management does not support cooperation/teamwork & 6 \\
\hline M29 & The management does not give us an opportunity to participate & 5 \\
\hline & \multicolumn{1}{|c}{ Total } & 36 \\
\hline
\end{tabular}

\begin{tabular}{|l|l}
\hline Seq. & lack of self-estimation \\
\hline
\end{tabular}


M25 My work position does not allow me to intervene in decisions

M26 Lack of awareness on some administrative issues

M33 My opinion will not make any impact

M41 I do not have the experience to discuss the work decisions

M49 I am afraid my colleagues won't support me in my opinions

M55 My participation will be dismissed

M56 I do not have the power or authority to change

M57 Lack of sufficient knowledge in legislation and regulations

M61 The inability to convince the others with my opinions

Total

6

6

5

4

3

2

2

2

1

31

\begin{tabular}{|c|l|c|}
\hline Seq. & \multicolumn{1}{|c|}{ Abusing of formal authority } & Freq \\
\hline \hline M9 & The management considers itself the only who has the right to take decisions & 8 \\
\hline M14 & The management is rigid in applying regulations and has no flexibility & 7 \\
\hline M18 & My administrator does not accept any debate about the decision & 6 \\
\hline M35 & The management does not raise the issues for discussion & 4 \\
\hline M45 & The management does not accept criticism on decisions & 3 \\
\hline & Total & 28 \\
\hline
\end{tabular}

\begin{tabular}{|c|l|c|}
\hline Seq. & \multicolumn{1}{|c|}{ Injustice } & Freq \\
\hline \hline M12 & The salary I get is not worth the efforts I do & 8 \\
\hline M23 & The management attributes the achievements to themselves & 6 \\
\hline M24 & The management does not differentiate between hard and inactive employees & 6 \\
\hline M39 & The management listens only to the opinions of selected people & 4 \\
\hline M47 & $\begin{array}{l}\text { The management does not fairly apply procedures in case of problems and } \\
\text { faults }\end{array}$ & 3 \\
\hline & \multicolumn{1}{|c|}{ Total } & 27 \\
\hline
\end{tabular}

\begin{tabular}{|l|l|c|}
\hline Seq. & \multicolumn{1}{|c|}{ Psychological withdrawal } & Freq \\
\hline \hline M27 & Being silent achieves me the tranquility & 6 \\
\hline M28 & If the decisions do not directly affect me or my work, I don't intervene & 6 \\
\hline M34 & I prefer to stay away from work issues and problems & 5 \\
\hline M44 & Nothing worth pay more efforts & 4 \\
\hline M51 & I am frustrated with my job & 3 \\
\hline M59 & To avoid contact with others in the work environment & 2 \\
\hline & Total & 26 \\
\hline
\end{tabular}




\section{Copyright Disclaimer}

Copyright for this article is retained by the author(s), with first publication rights granted to the journal.

This is an open-access article distributed under the terms and conditions of the Creative Commons Attribution license (http://creativecommons.org/licenses/by/4.0/). 